$\mathrm{H} \mathrm{V}$
3006
$N 5 B 4$
19202 


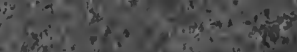

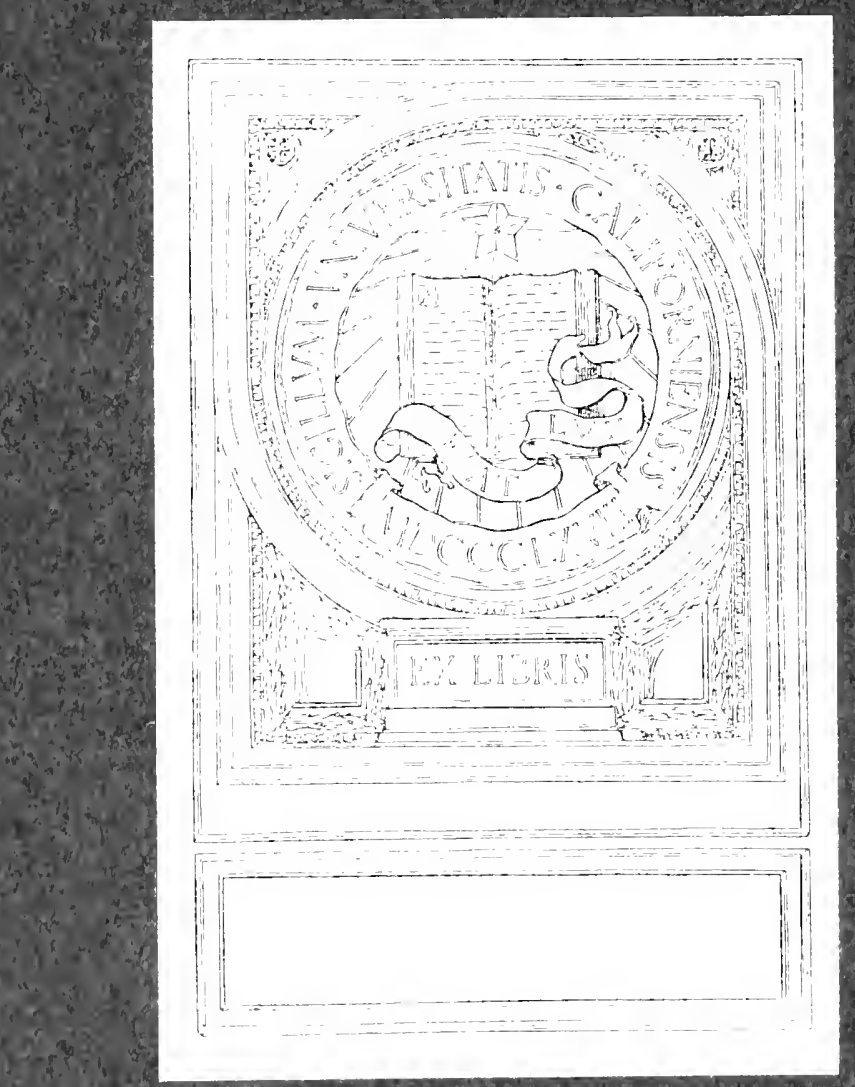




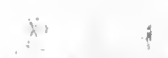

8

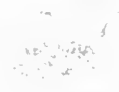

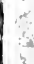

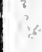

$x-4 b^{2}-4$
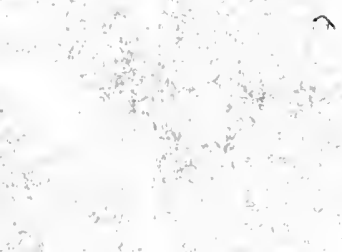

$\lambda$ 

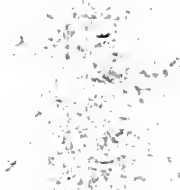

$2 x+$

t.

t. 解?

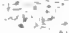

5

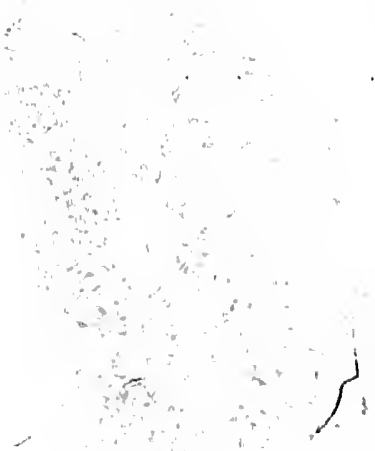




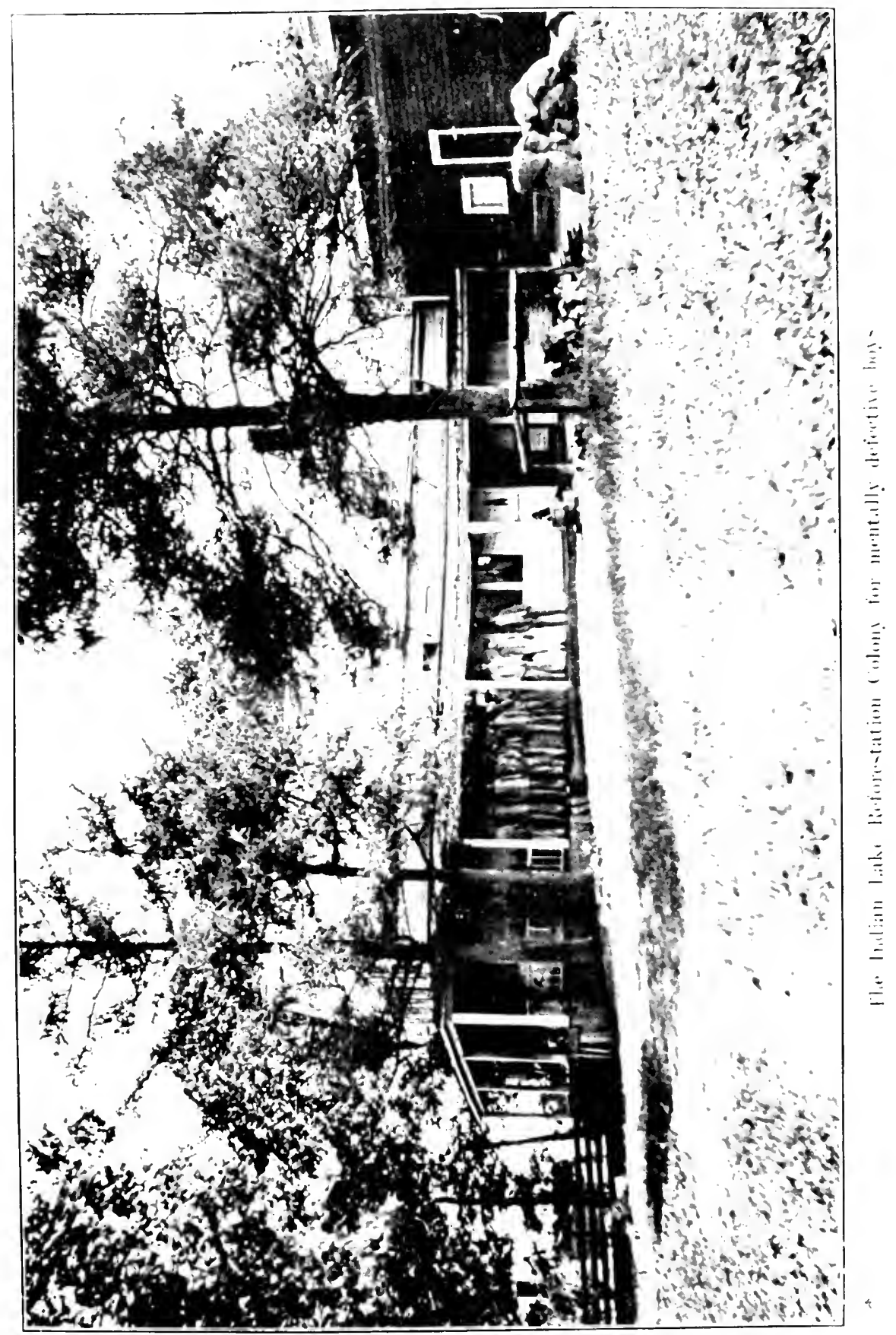




\title{
MENTAL HYGIENE
}

Vol. IV

JANUARY, 1920

No. 1

\section{COLONY AND EXTRA-INSTITUTIONAL CARE FOR THE FEEBLEMINDED}

\author{
CHARIES MERNSTEIN, M.D. \\ superintendent, Rome State Custodial Asylum
}

$\mathrm{T}^{\mathrm{T}}$ is very noticeable that during the last decade the type of 1 feebleminded that come to our doors for admission has greatly changed. Whereas ten years ago 80 per cent were idiots and imbeeiles and only 20 per cent border-line cases or morons, now only 20 per cent are of the idiot and imbecile class and 80 per cent are morons or border-line cases. I believe that one reason why we are receiving so many more of these social misfits or failures is that machinery has to a great extent displaced common hand labor, and more highly organized society depends more upon coöperative activities, thus demanding more specialized ability of its individual constituents. It is our opinion that the time has come when something much less expensive and many times more wholesome and natural than the physical custody of brick walls and iron inclosures and large per capita expenditures for buildings and yearly maintenance is possible and practicable for a large majority of these cases - that many of them can be rehabilitated and saved for something better than lives of institutional servitude, by careful training in the kinds of work that they are capalse of performing.

$B_{y}$ conscrative estimate, there are in New York State sone 30,600 feebleminded and socially unfit in need of care and treatment, at heavy burden upon the state if they are all 
to be maintained permanently in institutions. A system that renders a large percentage of them self-supporting, apart from the benefit to the individuals directly concerned, performs a threefold service: it relieves the state financially; it permits of increased facilities for the custodial care of the lower grades of feebleminded; and it adds to the community's supply of labor in fields in which the demand for workers is far in excess of the supply-namely, agriculture and domestic work.

The responsibility that rests upon us in this matter is further increased by the fact that we are receiving, not only a constantly growing number of border-line cases, but also many doubtful cases (under the law that allows us to take such cases for observation and study-Chapter 448 of Laws of 1912) in diagnosing which the best experts will differ as the case is seen from day to day. The one sure test as to the mental competency of such individuals to lead normal lives is, after thorough training, the world test. Many of them came from homes in which they have never known a normal family life, and many others have lived during childhood in great institutions, where little or no individual training, and especially no normal family domestic training, was available. The only fair treatment for these cases is to give them such training and then let them meet the test of life under favorable conditions in normal families, where they will have the benefit of the same kind of experience and the same kind of supervision and advice that go to the development of normal individuals. This is the method we are following in our boys' farm colonies, our working girls' colonies, and our parole system.

\section{Boys' Farm Colonies*}

Our first experiment in agricultural colonization was undertaken in 1906, when the Brush Farm Colony was established on a farm of 187 acres. On April 1, eignt inmates from among our brighter boys, with a supervisor and assistant matron as farmer and wife, took possession of this farm, marching away from the old asylum premises, led by the patients' band, with

- We have not gone into the same detail in our account of our boy's' colonies as we have in describing our colonies for working girls. as there appears to be little question regarding this procedure as applied to boys. 
a team and large sleigh, two cows, one extra horse, a few cooking utensils, one month's supply of food, and the eight patients' clothing and trunks. The legislature of 1906 gave us $\$ 1,000$ for furnishings, and with this money the house was made comfortable and tools were purchased for the farm. Four more boys were placed on the farm soon afterwards, making twelve boys there, and this number was later increased to twenty.

The financial statement of the colony for the first six months of its existence is of interest:

Credited with supplies to the amount of $\ldots \ldots \ldots \ldots \ldots \$ 1,573.05$

Charged with supplies to the amount of $\ldots \ldots \ldots \ldots \ldots \ldots \ldots \ldots \$ 904.26$

Salary of farmer and wife............. 360.00

Profit to eolony's eredit......... $\$ 308.79$

Two years later we established a second colony-the Bailey Farm Colony, which also accommodates twenty boys and a farmer and wife. This was originally a farm of only fifteen acres, lying between the asylum farm and the first farm colony, but we divided the acreage of the Brush Farm with it, giving one hundred acres to each.

In 1910 another outlying farm, five miles from the asylum, was rented for $\$ 650.00$ a year to be used for raising fodder and pasturage and for stabling our large herd of young stock. We have not, by the way, purchased a cow in twelve years, but have grown from our best calves the 160 cows we now have.

A fourth colony was started in 1912 on a neighboring farm of fifty acres, with accommodations for thirty boys, a gardener, and his wife. This colony supplies all the vegetables except potatoes nocelenl for our family of from 2,200 to 1,950 inmates and 250 employees. In 1915 and 1916 we rented two good dairy farms-one of 270 , the other of 200 acres-and placed thereon colonies of twenty inmates and dairies of forty milch cows each. These colonies produce milk for nearly all the butter that is needed in our regular dietary, in addition to producing all the milk needed.

A new experiment was tried in 1915 , when we sent a group 
of boys to the Adirondacks to do reforestation work for the Conservation Commission on the state preserves. This was planned as an economy for both the commission and the asylun. It furnished us with cheap beds and housing, and the commission with cheap labor, it being very hard to get labor in that remote district and very expensive to import it.

We had previously demonstrated that we could do this work successfully, having, under the supervision of the State Forestry Department, reforested forty acres of reverted state land, three miles soutl of Rome, and twenty acres of waste li:nd on the asylum farm.

On October 1, a group of twenty-five boys, with two attendants and a representative of the Conservation Commission, were sent to North River in the region of Indian Lake. The tents and cooking utensils for the camp were supplied by the commission from stock kept for such purposes. The trees were grown in the commission's nursery at Saratoga.

By Norember 1, the boys had set out 150,000 trees, covering 150 acres, and the report made by the commission showed that this work was much better done than it ever had been by paid labor or convict labor. The work was worth about $\$ 1,000$ to the state and actually cost us in direct expense about $\$ 400.00, \$ 200.00$ of , which was for railroad fares, $\$ 100.00$ for supplies, $\$ 75.00$ for labor, and $\$ 25.00$ for freight.

The success of this experiment led to the establishment of a permanent reforestation colony at Indian Lake. This colony is located on 150 acres of open farm land, where twenty boys live the year around and other boys come to camp in tents during the spring and fall planting seasons, the number depending on the number of trees available for planting. Fifty or sixty boys can do the house and farm work and plant $.500,000$ trees a year, in addition to caring for the nurseries which have been established on the farm for growing these trees from seedlings to the planting age of two years. On this farm the boys have produced all the vegetables, milk, butter, beef, pork, mutton, eggs, etc., needed for their maintenance and had excess products to sell. They have also been' able to make extra money by working on neighboring farms.

Because of the high cost of materials and the difficulty of shippiner tiem during war time, in the fall of 1918 we decided 
to discontinue this Indian Lake Colony, intending to reopen it as soon as conditions proved favorable, as we have found this kind of work very beneficial to many of our boys. It is surprising to see how many of them are anxious to go to the (amp and are glad to stay all winter, even though the place is so isolated. Indeed, the boys seem to glory in their isolation and in the fact that there is no one to interfere with them or irritate them and that they can practically have the run of things without being hindered or complained of by neighbors. A number of them, too, had opportunities to go out on surrounding farms to help cut wood, take care of stock, plant and harvest crops, etc., and several were placed on parole with farmers in the vicinity of the colony. Those of our boys who have incipient tuberculosis are greatly benefited by this openair life in the Adirondacks, and while regaining their health, are made happy by being able to do a little work.

Another of our colonies-the Isawrence, opened in 1918will be largely devoted to reforestation work. This colony is located on a 1,350 acre farm, with housing accommodations for forty boys. Only about 150 acres of it can be used for agricultural purposes; the rest is suitable only for reforestation. We planning arrangements with the State Forestry Department to establish on this farm a permanent nursery for growing trees, both for the use of the Conservation Commission at other points and for our use in reforesting the 1,200 acres available on this farm and the thousands of acres of waste land on adjoining farms, so far as the owners of such land wish us to do this work. Our proposition is that we will reforest land for our neighbors on a share basis, the state furnishing the trees and the inmates of this institution-the state's wardsdoing the work, and the state, at the end of a period of twentyfive or fifty years, taking a share of the timber product.

I believe that this is one of the largest and best pieces of work that we can do. It increases the value of the real estate, whether owued by the state or by private persons, and at the ind of a few years the state reaps its reward both from increased products and increased taxes. In this way we shall be making valuable and productive much waste land that otherwise would lie idle indefinitely, especially while labor costs as it cloes these days. 
A second boys' colony established during 1918 is on a small rented farm, about a mile away from the asylum, where we tried the experiment of caring for delinquent feebleminded boys under the colony system. We put in charge one of our experieneed attendants who had managed what we call the "lock-up" group-that is, delinquent boys who have to be kept either in locked wards or in squads of from twenty to forty, under the constant supervision of two attendants, when working out of the wards. This attendant's wife acted as house mother.

The experinent has worked out very well. We were ourselves somewhat surprised to find how little trouble the boys gave, and we believe that this scheme might be carried out further with larger numbers of boys, though each of the groups must be kept small and considerably isolated. Moreover, we appreciate the fact that the success of such a colony depends entirely upon the ability of some one who is especially fitted and trained to manage boys.

Requests were received during the year from Warsaw, New York, and from Jefferson County near Mannville for farm colonies, the boys to help surrounding farmers, but for various reasons it did not seem desirable to establish such colonies at the present time.

The following table shows briefly the situation with regard to our boys' farm colonies at the present time:

Boys' Colonies

No. 1. Brush. . . ......

No. 2. Bailey. . . ......

No. 3. Rathbun. . . ....

No. 4. Lamphere. .....

No. 5. Indian Lake. ...

No. 6. Stook. . ........

No. 7. Talcott. ........

No. 8. Kossuth. . ......

No. 9. Akron. .........

No. 10. Dewey. ........

No. 11. Lawrence. . . ...
Opened

1906

1908

1910

1912

1915

1915

1916

1917

1917

1918

1918
Acres

187

15

300

50

150

270

200

......

60

90

1,350
No. of beds

20 Purchased, $\$ 10,000$.

20 Purchased, $\$ 5,000$.

30 Rented, $\$ 600$.

30 Purchased, $\$ 5,000$.

20 Loaned by state.

20 Rented, $\$ 1,000$.

30 Rented, $\$ 1,000$.

20 Rented, $\$ 480$.

40 Rented, $\$ 700$.

20 Rented, $\$ 500$.

40 Rented, $\$ 600$.

290

All these colonies are for agricultural purposes with the exception of Number 8, which is for boys at work in Rome 
assisting in handling freight, caring for lawns, attending furnaces, shoveling snow, etc. All but Number 5 -the Indian Lake Colony-and Number 9, which is in Erie County, twenty miles from Buffalo, are located within a mile or two of the city of Rome. These farm colonies, each accommodating at least twenty inmates, cost the state between $\$ 5,000$ and $\$ 10,000$ apicce, or a rental of from $\$ 600$ to $\$ 1,000$ a year apiece, whereas to build large brick buildings costs from $\$ 500$ to $\$ 1,000$ for every inmate. Moreover, these colonies, after the first year, are self-supporting, including all expenses and 5 per cent on the investment.

One of the plans that we have in mind is to colonize with morons abandoned or unoccupied farms such as are to be found on nearly every crossroad in every township. In addition to earning their livings on these farms and improving the land and buildings, the boys would have spare time to put in helping neighboring farmers-who are much in need of such labor-and thus further contribute to their own support. At odd times they could pick and crush stone and distribute it on the small crossroads that form the connecting links between the state-improved roads. When these abandoned farms, through good cultivation, became sufficiently valuable, they could be vacated as colonies and the increase in their value, gained through sale or otherwise, either revert to the state or be used for further colonization.

\section{Working Girls' Colonies}

Our first working girls' colony was opened in 1914. The following extracts from our annual reports give a good description of the purpose and methods of these colonies and the success that has attended them:

\section{FIRST REPORT ON GIRLS' COLONIES}

The following announcement was made at the opening of the first colony:

Rome, N. Y. October 7, 1914.

A working girls' home has been established at 209 West Thomas Streettelephone number, $172-\mathrm{J}$-where girls are available for domestic work, sewing, ete., by the day, week, or month. The girls going out from this place to work are capable of doing all kinds of domestic work, except special cooking. They are only able to do common cooking. 
Their services may be secured by telephone. The rate is fifty cents per. day, and their servioes will be available for employment at any time on short notice.

Settlement for servies will be paid direct to the manager of the home. Bills will be regularly rendered weekly for such services.

These girls are not markedly defective, but are girls who have becil orphans or have never known a normal home, and when hater in life they have gone out into the world, they have been unable to get along becauso of lack of proper home training and normal worldly experience. As a result they were sent to this asylum for stury, are, and training, and we are sending them out to work, after having beon thoroughly traines] and tested here, to see if they ean get in touch with the world under nermal conditions and thus learn to bo solf-sustaining and possibly have their. untire freedom.

This colony is carried on in a rented house in the rity, which constitutes the girls' home and social center, presided over by a housekecper or matron. with a social visitor to inspeet their working places and their street deportment, to accompany them to moving-pieture shows and other sori:l diversions, and to assist them in purchasing their elothing, etc. We hope in this way to have many of these girls learn through experience normal soeial reactions and family life, and thus to return the services of many. of these willing and competent domestic workers to sociely and in this way lighten the load and make state care and supervision possibla for all this class of dependents who positively need such care. Incidentally, in connection therewith we have established the most positive test possibl." as to the ability of some of these eases to rehabilitate or support thenselves, regarding all of which we ean never be positive in a considerable number of these border-line cases until such world test has actually been applied.

Of the sixty-seven girls who worked through this colony during the first year, forty-two remained at the end of the year, and twenty-five were returned as follows: nine for social offenses, such as flirting on the street, boisterous on the street, noisy at the colony, etc. (only two were really serious social failures); nine of the younger girls because they liad not had sufficient training; and seven others because of sickness, or because their services were worth more to the institution than they were getting outside-namely, $\$ 3.50$ a week-and they preferred to live and work at the asylum.

The very marked inıprovement occurring in these parole cases is most favorably commented on by all who come in contact with them, and there is no doubt but that it is just these normal experiences in life which these eases lacked in their earlier environment and the absence of which in their lives 
during their habit-forming period was the real cause of their previous misfit or failure.

These girls served 226 families in Rome during the year. A number of the girls work one or two days a week at different places, about half of them having regular places where they stay continuously.

They earned $\$ 3,278.91$, thus making themsclves entirely selfsupporting, with all bills paid and money in the bank to thr colony's eredit at the end of the year, as well as each girl, in addition to having paid for all her own clothing, having an individual savings-bank account. One girl had as much as fifty dollars in savings to her individual credit.

It required about one-third of the earnings of these girls to support the colony, including the cost of furnishings, rent, provision, ete.

Each girl is given twenty-five cents each week for spending money, and fifty cents cash each week for the savings bank. The remainder of all money collected is placed in the bank for general expenses, clothing, etc., and each girl is griven money from the general fund for all necessary or reasonable purposes.

I do not hesitate to declare that the results of our year's experience amply justify us in deciding to go on with the work, and surely the general interest manifest in the experiment, if such it may be called, as indicated by the many letter: of inquiry-among which may especially be mentioned those from the state boards of charities of Maine, Virginia, and Indiana, the State Department of Education of Connecticut. etc.-warrant the assumption that organized charity is awaiting avenues of social relief along these lines.

\section{SECOND REIPORT ON GIRLS' COLONIFS}

On September 1, 1916, a second girls' colony was opened in a large rented house, two eity blocks removed from the first girls' colony, where ten girls between fourteen and sixteen years of age are to remain one year in home training befor. they go out to work, and thus, we hope, become even mor. efficient domestic workers. In addition to these ten younger. grirls, there are eight older working girls living at this colony. and a portion of their carnings, with a portion of the eaming: 
of the other colony, will be used to support this second colony and make possible this better training of ten of their younger sisters in need. Too, the older girls will be stimulated to set good examples to the younger girls, and the younger girls will be stimulated to do their best to hold their place and later to have the same chance the older girls are having, especially the larger freedom and finer clothes; the latter especially appeal to girls.

Night school has been established at the colony, where sewing, cooking, and book school are carried on, and we have been pleased as well as surprised to find the interest the girls manifest in these activities, even the girls who room and sleep where they work coming in for this work in preference to going to the movies.

Financial Statement, October 1, 1915 to October 1, 1916

Received from 247 customers.................... \$5,418.82

Fifteen boys earned.................... $\$ 494.00$

Ninety-one girls earned................ $4,924.82$

$\$ 5,418.82$

Paid boys in cash, etc.................. $\$ 150.92$

Paid girls, eash, clothing, etc............ 3,173.64

Fixtures and furnishings................ 569.67

Expense (gas, water, phone, etc.) ........... 229.47

Rent ............................ 410.00

Extra salaries . . . . . . . . . . . . 120.00

$\$ 1,329.14$

$\$ 4,653.70$

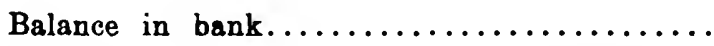

$\$ 765.12$

Fifty girls have a total of over $\$ 1,000$ in the savings bank to their individual credits.

Number of girls passing through . ............ 91

Number of girls paroled through . ............ $36 \quad 36 \quad 17$

Number of girls discharged after parole.......... $13 \quad 7$

Number of girls discharged direct from.......... $13 \quad 11$

Number of girls returned from parole . . . . . . . . $14.14 \quad 6$

Number of girls returned from discharge . . . . . . $3 \quad 3$

Number of girls remaining on parole............. 94

Number of girls remaining in colonies.......... 53 
Girls designated "institution" did not pass through colony training. About one-fourth of the girls go back and forth from the asylum to the city of Rome by bus, about one-fourth live at the colonies, and about one-half live where they work, thus making a sort of progression in their parole to larger freedom and responsibilities.

\section{THIRD REPORT ON GIRLS' COLONIFS}

During the year [1917] two additional colonies have been established for girls, one at Westleigh, Staten Island, for girls at domestic work, and the other at Oriskany Falls, a colony for girls at work in a knitting mill. Requests were made for several additional colonies. However, we were unable to organize more this year because of lack of trained girls for the purpose who could be spared from our regular service, especially this year when so few good and reliable citizen employees are available for attendants and other regular service. Thus many of our most reliable boys and girls were pressed into service at the asylum instead of being given other privileges through colony life or parole. And here the question arises, is it fair and just to these boys and girls to deprive them of an opportunity to live outside the institution, so long as they are capable and trustworthy? However, we have not hesitated to do this in view of the pressing war emergency, just as soldiers are used everywhere under such exigencies.

Gloversville, Fort Plain, Fonda, Canajoharie, Hamilton, Oneida, Canastota, East Aurora, and Utica have all asked for girls' colonies, and several opportunities have presented themselves for other farm and industrial colonies for boys. Of course we require some little overhead capital to start boys' farm colonies-such as for implements, teams, seed, and fertilizer, as well as for house furniture-and thus, while we prefer to extend boys' colonies along agricultural lines, and scatter them about in sparsely settled communities, so that the boys' labor may be made available to assist as many farmers as possible, still it is much cheaper and more paying in immediate return, especially in these times, to start industrial colonies for both boys and girls to work in mills and at day's labor. However, it is our experience with these boys and girls, as with normals, that they have their preferences; some 
boys like farm life best, while others like mill work, etc., and some girls like housework best, while others take to mill work or sewing or laundry work.

We believe that at the present time the largest and best outlet for girls' labor is hand sewing and hand laundry, and these lines of work are especially adaptable to colony life for a large number of girls who cannot be trusted so far as to go away from the colony for indefinite intervals, as is required where girls go out for housework.

The mill colonies, too, are especially well adapted to meet the requirements of a large number of girls who need continuous supervision, as the supervisor or attendant who goes to the mill with the girls acts as forewoman over them, and she can quickly learn the varions operations and then act as instructor to the new girls as they enter upon the work; and herein again are the mill operators especially pleased with the arrangement.

Since October 1914-three years-200 girls have passer through the girls' colonies, and only 35 have been permanently returned, leaving 165 still ont earning their own living. Of this number 77 have been paroled, and 63 discharged after parole, 14 still remaining on parole, and 88 remaining in the colonies.

Of course the greatest good in this colony activity, in addition to giving these girls larger opportunities for development, is that beds were made available for 165 additional girls, all of whom were greatly in need of such training and custody, and nearly every one of whom would otherwise have drifted further into crime and immorality and other troubles.

Number of girls passing through colony........... 200

Namber of girls paroled . . . . . . . . . . . . 77

Number of girls discharged after parole........... 63

Number of girls remaining in colonies............ 88

Number of girls returned to asylum............ 35

Number of girls cared for in colonies first year.......66 (new) 67

Number of girls in colonies second year............ 91 (new) 45

Number of girls in colonies third year........... 96 (new) 6.4

The girls from the colonies are frequently met in groups and talked with about some of their failures or adverse experiences, as well as their exemplary experiences, so that all may 
have the opportunity to profit through the mistakes as well as the successes of others, and it is really surprising to see how kindly they receive these suggestions and how hard they strive to meet the approbation of their supervisors and especially that of the superintendent. Individual evidences of more than ordinary success could be cited by the score where the girl in a lousehold has especially and repeatedly exerted herself to please and even surprise "my lady," as they always designate the housewife for whom they are working. A girl goes and purchases fifteen cents worth of graham flour with her own money in order to surprise the family at breakfast with graham gems. Another tells the garbage man not to pound the can to loosen the frozen garbage, as she will get the teakettle of hot water to pour on the outside of the can to loosen it. Another asks the housewife if she can sit at her feet on the floor childlike and help her mend during the afternoon, rather than go out to the eolony. Numbers ask to be allowed to take samples of their eakes and pastry to the superintendent, for him to sample and see how well they did.

To be sure, we did experience in the beginning attempts to discourage the project, such as a series of anonymous postcards sent to the women who were employing the girls, stating that they should be ashamed to employ seab labor, etc., all apparently from one source, a discharged and disgruntled former employee. Also, a group of boys attempted to molest and distract the girls on the street and loitered about the colony house, but the early coöperation of the police served to quiet all such disturbances.

We took the precaution of not starting out with definitely fixed or preconceived rules of procedure which might hinder or be impractical for natural development, but rather preferred to develop as we proceeded in the work, allowing our experiences, and especially the results of our conferences with the girls, to serve as suggestions rather than rules for future conduct.

We began with each girl so far as possible a new life and thus preferred that those who were to meet and work with them through the colony should have no basis for a biased judgment against them. We therefore decided that the colony officials should know nothing definitely of the girls' past 
history, giving each girl the best chance possible to bury her past if she were so disposed; and one need but see the letters of advice that some of the girls write back to their girl friends remaining in the asylum to appreciate that at least some of them do attempt to bury the past and come to learn that goodness and virtue are their own reward.

As regards the benefit to each individual inmate under such a scheme of colonization as herein outlined there can be no reasonable doubt after an observation of the results of the work, and while some extremely technical and pessimistic observer might find a few startling exceptions to this statement, still a few failures are to be expected in almost any line of endeavor, and when they do not exceed 2 per cent of the cases handled, we certainly should not let these few failures be the sole guide to our future work in the care and treatment of the other 98 per cent; not even should the failures reach a percentage of 10 -which they never have-should the result influence us too much in our work with the remaining 90 per cent.

\section{Aditional Girls' colonies onened}

In view of the success of the girls' colonies already established and the growing demand for them from various communities, we decided to open two new ones during the past year (1918). One-opened July 1-was at East Aurora, where a matron and twenty girls were placed in a house with a monthly rental of $\$ 40.00$. This has been the most immediately successful of any of the colonies that we have established. From the very beginning, it has been almost entirely self-supporting, paying all its own bills and having very few supplies sent to it from Rome. As a rule, it has taken us from six months to a year to get a colony on such a paying basis, but because of favorable circumstances, the demand for labor being great in the summer of 1918, the girls found ready employment without loss of the time usually spent in introducing the proposition to the comnunity. While these girls have been able to place very little money in the savings bank, because of the high cost of all commodities, they are a most happy group and none of them would think of coming back to the asylum to live.

In the same month we opened a colony at Syracuse, where 
we were able to take over a property with accommodations for from forty to sixty beds, formerly the Syracuse Shelter for Unprotected Girls. Because of the modern system of probation and parole in the juvenile and municipal courts, which tends to save nearly all the normal girls from reformatory terms, leaving only the abnormal to be placed in such reformatories and shelters, we were able to get this property at the very reasonable rental of $\$ 100$ a month, including complete furnishings. It includes a chapel, a gymnasium, a department for adults and a separate department for younger girls, and large yards, and is certainly very desirable for our purposes, with the possible objection that it is too large and too much like an institution to constitute an ideal colony home. However, it is well situated in the center of a prosperous development section in Syracuse, where new homes are being built by well-to-do families, which means plenty of work nearby for the girls. Also, the project has the backing of many influential women in Syracuse who contributed toward the property with the idea that it was to be used for the care of friendless girls and who are glad to see it devoted to a like purpose. They feel that this colonization of high-grade fecbleminded and border-line girls is really a continuation of the work that they had been carrying on for some years without recognizing a number of their girls as actually of this class.

The property, with furnishings, is valued at $\$ 40,000$ and we were given the option of purchasing it for $\$ 30,000$. The annual rental of $\$ 1,200$ is to be continued at our option, also.

The Shelter formerly had bars on the windows. These have been taken off, and some of the high board fences surrounding the property have been removed. This has pleased the people in the neighborhood, as it makes the place look less like a prison.

This colony, too, started out under very favorable conditions, but an outbreak of influenza resulted in the non-employment of most of the girls for nearly two months, which greatly cut into our income. However, conditions soon returned to normal, and we are now receiving sufficient income to put money away in the bank.

It is interesting to note that in the case of both of these colonies-East Aurora and Syracuse-no one objects to the 
presence of the girls and every one is favorably impressed and anxious to see the project succeed. This is true not only of the people who employ the girls. Many others are interested in seeing the movement carried on, especially those who have had a chance to see the improvement that takes place in the girls as a result of the larger opportunity for individual development which the colony affords and which the institution could not possibly provide; nor could any system of parole provide it without the colony as a social center for the girls and a protecting influence over them.

The Syracuse colony took the place of the one on Staten Island, which we decided to close. The experiment of conducting such a colony at a considerable distance from the institution-about 250 miles-had been carried on for a year and had proven the plan entirely practicable and satisfactory. But labor and food conditions becoming somewhat difficult because of the war. we thought it best to remove this colony to some place nearer Rome, where the exchange of help, inmates, and food supplies could be managed at less expense.

The closing of this colony met with considerable protest from the people who were employing the girls, they feeling that they were being deprived of a very great accommodation and convenience. Many of the girls, too, who were working through the colony felt that they would rather stay at Staten Island among the friends that they had made than return to Rome or go to a strange colony.

The list of our girls' colonies is as follows:

Girls' Colonies

No. 1. Evans (Closed 1919) .... 1914

No. 2. Mason............. 1916

No. 3. Staten Is. (Closed 1918)

No. 4. Parry..............

No. 5. Oriskany Falls........

No. 6. East Aurora..........

No. 7. Syracuse...........

No. 8. Robinson.............

No. 9. Richfield Springs.......

No. 10. Hamilton...........
Opened No. of

beds

1917

1917

1917

1918

1918

1918

1919

1919
Cost

Kind of

Colony

14 Rented, \$420. Domestic

18 Rented, $\$ 600$. Domestic

10 Rented, \$480. Domestic

18 Rented, \$480. Domestic

24 Rented, \$480. Mill

20 Rented, \$480. Domestic

40 Rented, $\$ 1,200$. Domestic

20 Rented, \$480. Domestic

24 Rented, \$480. Mill

20 Rented, $\$ 300$. Domestic

These girls' colonies are all located in the city of Rome except Number. 3, at West New Brighton, Staten Island, 


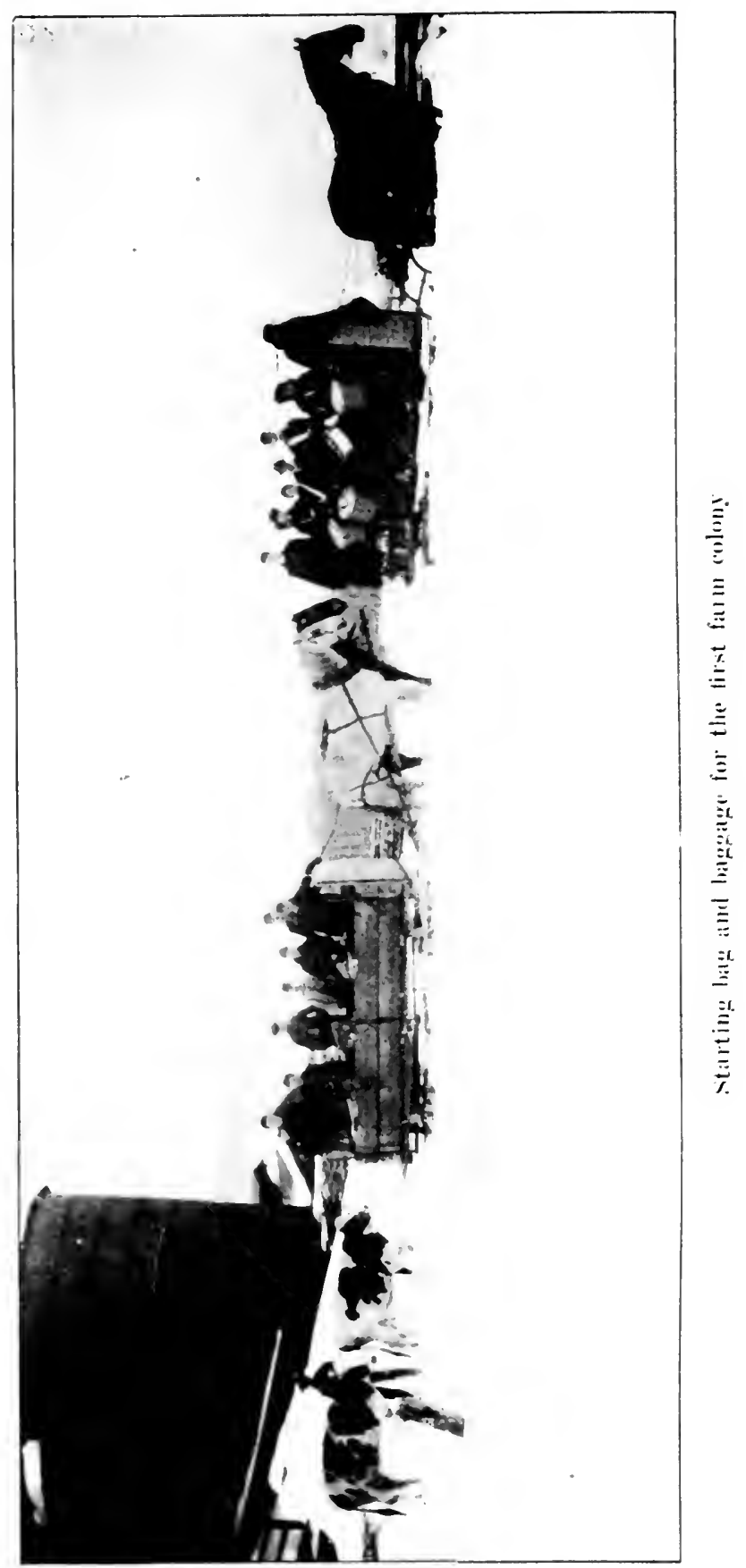




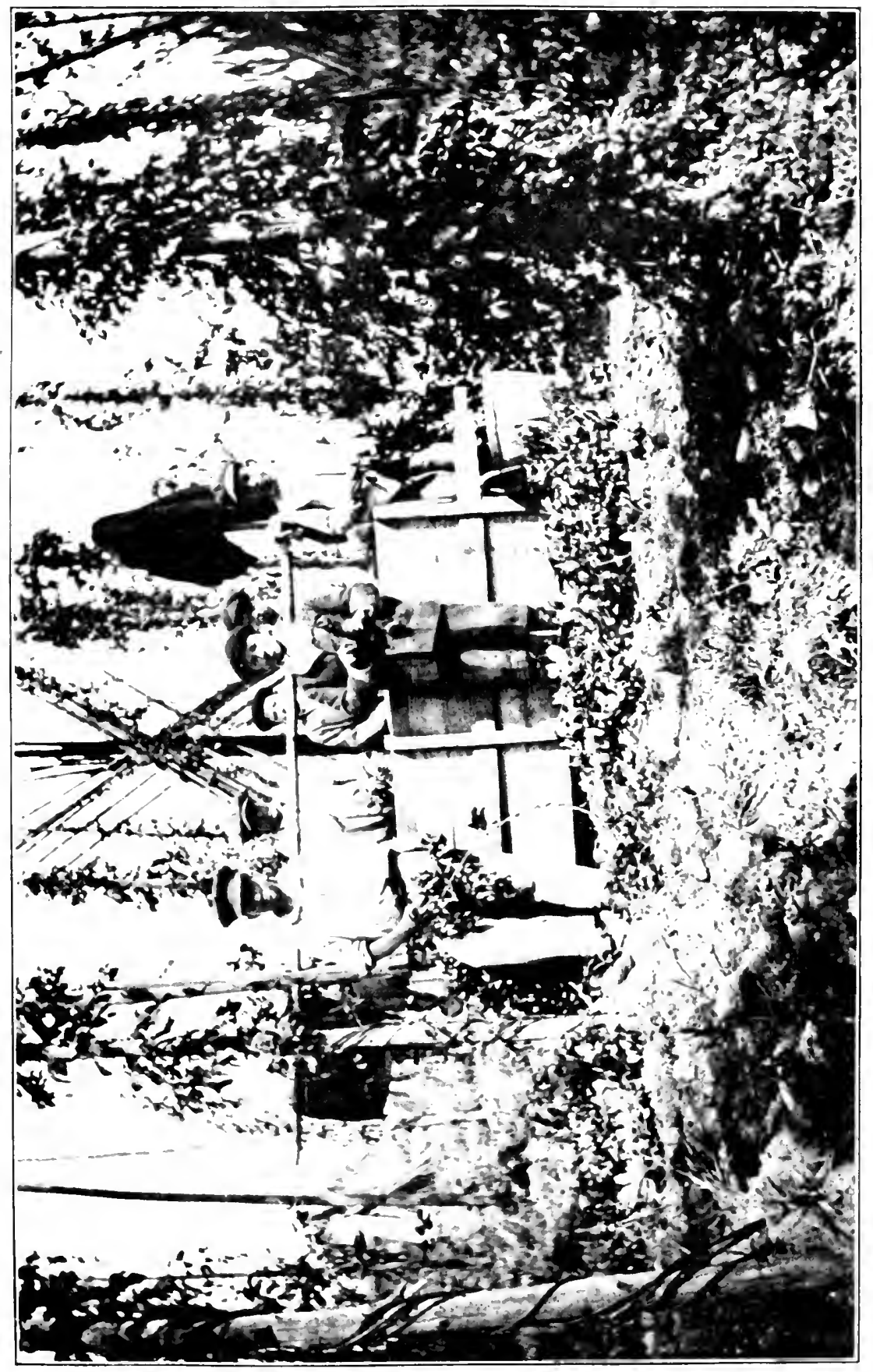


N. Y.; Number 6, at East Aurora, N. Y.; Number 7, at Syracuse, N. Y.; Number 10, at Hamilton, N. Y. (for colored girls at lomestic work); Number 5, at Oriskany Falls, N. Y.; and Number 9, at Richfield Springs, N. Y.

Each of the colonies for girls at domestic work really cares for and oversees a larger number of girls than the bed capacity of the colony indicates, as a number of the more trustworthy girls, after a few weeks or months at the colony, are allowed to sleep at the homes where they are employed. They must, however, report to their home colony at stated intervals, as well as generally for social diversions, special directions, etc. That is, the colony house serves as a home and social center for all.

The grirls' wages have now been increased to $\$ 1.50$ per day, or $\$ 5.00 \mathrm{by}$ the week, and they are allowed fifty cents a week for spending money. The remainder of the earnings of each colony are placed in a general fund, from which supplies, clothing, etc., are purchased, each girl being charged with her personal clothing and other expenses. A complete individual account is kept for each girl.

The situation, put briefly, is this: On October 1, 1914, we had 450 girls in this institution. Between that time 'and July 1, 1919, we have admitted 675 , making a total of 1,125 yirls eared for, of which number 362 have passed through the rolonies; that is, practically one-third of all the cases cared for and admitted since October 1, 1914, have received colony training and treatment. Of this number 225 have never had to be returned to the institution-that is, have clean recordswhich is 20 per cent of all the cases cared for during those five years. This proves the truth of the statement that I have been making for the past year or two-that from one-third to one-fourth of all the cases we deal with are adapted to colony life; for while only one-fifth of all the cases have proven successful at the first trial, still the records show that 131 of the cases were tried again and that finally only 28 had to be returned permanently for discipline. Actually over onequarter of all the cases cared for since October 1, 1914, are still cared for outside of the institution-that is, are not occupying $\$ 1,000$ beds in the institution.

'The financial statement of the girls' colonies from July 1, 
1918 , to July 1, 1919, is the best proof of their success from that point of view.

Financial Statement of Girls' Colonies July 1, 1918-July 1, 1919

\begin{tabular}{|c|c|c|c|c|}
\hline Colony & Earnings & $\begin{array}{l}\text { Paid Girls } \\
\text { from } \\
\text { Earnings }\end{array}$ & $\begin{array}{l}\text { Operating } \\
\text { Paid from } \\
\text { Earnings }\end{array}$ & $\begin{array}{c}\text { Expenses } \\
\text { Paid by } \\
\text { State }\end{array}$ \\
\hline Rome Group . . ..... & $\$ 7,300.70$ & $\$ 4,198.35$ & $\$ 3,293.94$ & $\$ 5,118.45$ \\
\hline Oriskany Falls . .... & $9,154.23$ & $3,832.41$ & $5,276.39$ & 94.84 \\
\hline East Aurora . . ..... & $4,337.16$ & $1,155.14$ & $2,695.81$ & 672.86 \\
\hline Syracuse . . . . . . & $3,311.87$ & 980.56 & $2,338.44$ & $2,493.33$ \\
\hline & $\$ 24,103.96$ & $\$ 10,166.46$ & $\$ 13,604.58$ & $\$ 8,379.48$ \\
\hline Salaries . . . . . & 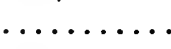 & 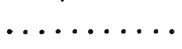 & 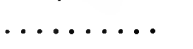 & $3,620.52$ \\
\hline In round numbers.... & $\$ 24,000.00$ & $\$ 12,000.00$ & $\$ 12,000.00$ & $\$ 12,000.00$ \\
\hline
\end{tabular}

The average earnings of 140 girls (the average number of girls in the colonies) were $\$ 165$ each for the year.

The cost to the state was an average of $\$ 85$ (supplies $\$ 60$ and salaries $\$ 25)$ per girl per year, whereas it cost $\$ 280$ for each girl at the institution.

A daily average of 140 working girls, ${ }^{*}$ distributed among six colonies-three domestic colonies in Rome, one domestic colony each in Syracuse and East Aurora, and a mill colony in Oriskany Falls-earned last year $\$ 24,000$. One-half, or $\$ 12,000$, of these earnings was used for personal expenses and savings for the girls, and the other half for colony operating expenses, while the state expended an equal amount-\$12,000to supplement operating expenses. Thus, the support of these girls actually cost the state $\$ 85$ per girl per year, whereas the per capita cost at the institution was $\$ 280$ for the same period. Of course, the support of these working girls at the institution would actually cost less than the average yearly cost, as they would all be workers and contributors to the general household economy and would not require the expense of special school training or medical attention. On the other hand, they would require more expensive clothing than the average girl inmates in the institution, and, too, a house and bed, the cost of which does not appear in the per capita cost of $\$ 280$; whereas in the colonies they not only paid for their

- There were as many as 160 girls at times in colonies, in addition to from 16 to 20 younger girls in training in junior colonies, maintained by the earning colonies. 
own homes and beds in rental, but also contributed home, bed, and board for from sixteen to twenty younger non-earning girls.

The $\$ 12,000$ used by the girls for personal expenses, savings, etc., represents the privileges and comforts offered to the colony girls by this freer life, such as free spending money, better clothes, church and social privileges, savings in the bank, etc.

Girls Passed Through Colonies October 1, 1914 to July 1, 1919

\section{Discipline}

Total number passed through eolonies.................... 362

Number never returned for discipline................... 225

Number returned for discipline and tried again.............. 131

Number returned permanently for diseipline................ 28

Number returned permanently for incompetency or ill bealth..... 55

Parole

Number paroled through colonies.................... 136

Discharge

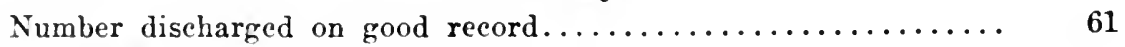

Numberidischarged as runaways....................... 22

\section{Runaways}

Number runaways from colonies 30 , from parole $22 \ldots \ldots \ldots \ldots . \quad 52$

Number runaways discharged (including married, paroled, or lost). $\quad 22$

Number of runaways returned........................ $\quad 30$

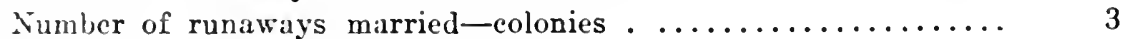

Number of runaways married-parole . . ................ 7

Number of runaways immoral-colonies . ................ 7

Number of runaways immoral-parole . . ................ 4

Number of runaways lost-colonies . . . . . . . . . . . . . . . 2

Number of runaways lost-parole $\ldots \ldots \ldots \ldots \ldots \ldots \ldots \ldots \ldots \ldots \ldots$

\section{Children}

Number of babies born to colony girls................... 0

Number of babies born to parole girls.................. 9

of the 9 babies born to parole girls:

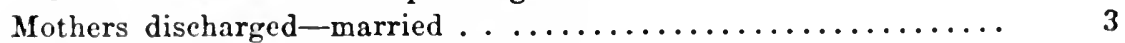

Babics born in institution $(3$ died) $\ldots \ldots \ldots \ldots \ldots \ldots \ldots \ldots \ldots \ldots \ldots \ldots \ldots \ldots$

Babies born outside and adopted..................... 1

\section{Parole Cases}

Under the law of 1912 which provides that paroles may be granted to inmates to test their ability to live outside the institution, we have paroled 240 girls and 276 boys. Our 
parole system is resely eonnected with our colony systen, the eolony serving as a step in the progression to larger freedom and larger responsibilities. Before we adopted the colony plan, many boys and girls who went out on parolo became lonely and homesick and longed for association with friends and aequaintances; and when their work was done, rather than remain alone, they would tend to drift to the streets and associate with whomerer they met there. Naturally, under these conditions, they either made undesirable acquaintances or beame so homesick that they begeed to be allowed to return to the institution, or actually did retmen of their own aceord, having no friends or relatives to whom to gro. This experience was one of the reasons that led us to adopt the colony plan, to help these cases gradually get back into touch with the world and learn the ways of the world and how to care for themselves, and at the same time to grive them some place that they can call home while they are making their new associations and friendships, thus protecting they from unprincipled people and bad companions during their rehabilitation period.

The employment of a full-time parole agrent to investigate homes and supervise the parole of girls, including the girls in the out-of-town colonies, has been a most helpful measure, and has served to relieve the superintendent considerably of all this detail, as well as making it possible to supervise and direct these girls more closely. We consider all the boys and rirls in out-lying colonies as on parole, even though they are under the care of an employee of the institution, who lives with them as supervisor or house matron.

REGLLATHONS GOVERTING PAROLE

The regulations that govern parole cases are as follows:

1. Application in writing shall be made to the superintendent by the person wishing to take an immate on parole, and the home wherein such inmate is to be placed shall be investisated by the superintendent or his agent.

2. The person taking an inmate on parole shall sign an agreement in duplicate, one copy of which shall be filed at the asylum and the other given to the person taking the inmate.

3. Females shall not be paroled into homes such as public 
places, hotels, boarding liouses, hospitals, or places where there are transient or frequently changing residents or population.

4. The superintendent shall report to the board of managers at each monthly meeting the names of all inmates placed on parole during the past month, and the names and addresses of the persons in whose homes such immates have been placed.

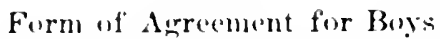

I hereby agree to take....................... to live with and work for me with the understanding that after he has been with me four weeks. I will decide whether or not he proves satisfactery.

I agree to pay him $\$ . . .$. . pere month, with board and lodgine.

I anger to report at least cones in three months on how the boy is gettine along, and make eomplete settlement.

I will take receipts for all elothing bought for the boy. and keep close aceount of the spendine noney I give him, which is not to exceed 25 eents per weet, or \$1.00 at aly one time, if he is going to town, and the balanee due at the end of eac! duarter will be left at the asylum for the boy.

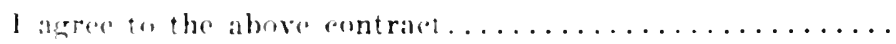

\section{Notice}

boys rovine unt on parole arre not allowed to smoke. If they have the habit before going ont, they will be allowed to rhew twhaceo, but under no conditions will they be allowed to smoke.

\section{Form of Agreement for Girls}

I herely argee to tirke..................... to work for me, with the understanting that atter she has been with me four weeks I will deede whether or not she proves satisfaetory, and I agree to pay her $\$ 3.50$ per week.

I aplese to repurt at least onere in three montlis on how the grirl is getting alone and make complete sottlement for her services. I will keep aceurate ace..mm wi ail money iven her, and take receipts for all elothing houglit

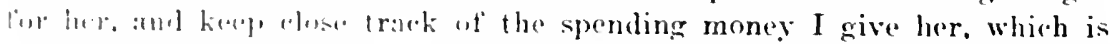
mot to rxeent 25 rents a week for general spending money, or $\$ 1.00$ at any whe time for sperial areasions. and the balanes of the money due her at the eall of earel priarter will be lett at the asylum for the girl, the understanding heing that it is to be placed in the savings bank to her individual rredit. 
Also, the following notices were sent out to the employers of boys and girls on parole:

\section{FIRST NOTICE GIVEN TO EMPLOYERS}

The boys and girls who are sent out from this institution to work in Rome, and on parole elsewhere, are boys and girls who have proven themselves trusty at this institution and pretty eapable workers, along the lines of general institution work, such as domestic work, farm and garden work, ete., and while we do not consider them expertly trained in these lines of work, we do consider them good helpers. Of course, they need a little supervision to direet them in their work, at least until they learn to do the work in the way in which their employer would like to have them do it. They also need supervision and direction in their social life and street deportment.

Our object in sending these boys and girls out is that they may learn to live outside in the world and become self-supporting and at the same time vacate beds at the institution for more needy cases, especially younger boys and girls who need the training which they can get in an institution of this character, and for whom there is no other place.

We feel that the training in normal home life and household work and outside responsibilities which these boys and girls will receive in this way is really worth more to them than the money payment which they receive, and it is for the above reason that we allow them to go out to work for the small pay asked, hoping that after they become competent trained helpers and have proven themselves trusty and worth more, for instance, after a year of such service and training, they will receive compensation equal to the value of the work they then perform.

Many of these boys and girls were taken by social workers from very bad homes, where poverty, alcoholism, and other vices and lack of parental eare prevailed, and placed here or in other institutions or homes for care, training, and protection, or were finally sent to us for further care, study, and training, and we are now sending them out to receive their finishing training and the final world test as to their ability to make good. 


\section{SECOND NOTICE TO EMPLOYERS}

Where girls are sent out on parole to work in families, we are very anxious that the woman of the family should treat these girls very much the same as she would treat her own girl as regards controlling them in their street deportment, in spending their money, buying clothing, attending church, and matters of this kind, remembering that while these girls are apparently full grown or large and of adult age, still their mentality is retarded or subnormal, as they usually have a mental age of about eight to ten years, and therefore we cannot expect them, at first at least, to use much better judgment regarding their street deportment and actions outside of the house than a girl of that age would use, even though they are able to do a great deal of work, etc., as a girl their size ordinarily would do.

This work they have learned to do by experience, watching and assisting older ones do it, but they have never had any special training in street deportment, spending money, etc., and thus they need special close watching, training, and opportunities for correct habit forming along these lines.

They should not be allowed to go to picture shows alone in the evening, or even in the afternoon very far away from home, or be allowed on the street alone in the evening or on Sundays.

You should not hesitate to make them mind just the same as you would your own girl of eight to ten years of age, and if they do not do this agreeably, or if they tend to lie and deceive you, you should let us know at the institution at once. We are trying to have these girls learn how to live outside decently, and be helpful, and it is with this in mind that we send them out in this way, but if they don't improve by the experience, or tend to grow worse, and also if they lie and try to deceive you, they should be returned to the institution at once for further discipline and training.

They should save at least one-half of the money which they earn, to place in the savings bank as per direction in the agreement which you have signed. They must mind, be orderly, respectful, and honest as long as they remain out, or otherwise be returned. 


\section{Orservation Cases}

The law of 1912 which permits us to take cases for observation, in order that a careful examination may be made of their mental condition, has resulted in our recoiving a number of such cases.

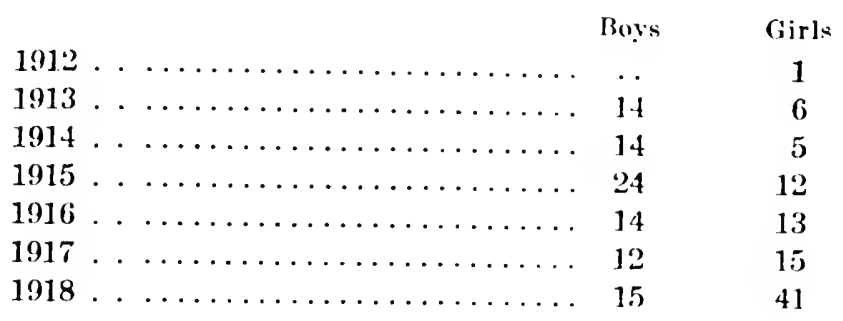

Arrangements have been made whereby we receive observation cases from the reformatories and sehools for delinquents in New York State; that is, before inmates are discharerel from these reformatories or schools, they are sent to Rome and retained here for a time to test their mental capacity. If a case proves to be feebleminded, arrancements are marla for commitment to Rome; or boys and ails who are well trained. and old enough to take up colony life. are within a short time placed under colony management to test their ability to load such a life. Later, if it is desirable or posible, they are sent ont on parole.

Cases have been aceepted from the Hudson Trainine silhool for Girls, the Bedford Reformatory for Women, the Albion Reformatory for Women, and the Valatio State's Prison for Women, and we have arranged with the Prisons Departunent to test out in this way additional women, between the ages of twenty and forty, from the state's prisous, where thero is a question whother or not the case is feebleminded. That is, before the woman's sentence expires, she may be paroled from the state's prison to liome aud kepi here under observation for a short time. If it is decided that she is feeblemindrel and a proper case for institutional or colony care, she may br conmitted to Rome before the expiration of her prison term, and thus be kept in custody and prevented from further drifting into crime or immorality. 


\section{SIMMARY}

We have been carrying on colonization with the feebleminded for the past twelve years and have proved it practical, economical, and feasible in every way.

We have at present ten farm colonies for boys, with at least twenty immates and farmer and wife on each, living comfortably in the old farmhouse on one hundred or more acres of land. Such farms cost the state between $\$ 5,000$ and $\$ 10,000$ each, or a rental of from $\$ 60(0)$ to $\$ 1,000$ a year, while institutionall buildings cost at least $\$ 500$ to $\$ 1,000$ for each inmate. Also, those colonies are self-supporting after the first year, including all expenses and 5 per cent on the investment.

We have one colony for boys at work in Rome, such work including gardening, caring tor lawns, shoveling snow, tending furnaces, etc.

We have eight eolonies for girls in rented houses in the city of Rome and alsewhere about the state, where from 160 to 250 irirls, under the supervision of matrons and parole agents, are supporting themselves doing domestic work, hand lanndry. sewing, and mill work.

The purpose of these eolonies is to test out the boys and erirls in an existence more nearly normal than is possible in a large institution. The privilege of colony life is given only to sclf-respecting boys and grirls of reasonable intelligence. who wish to make an offort to be self-sustaining, law-abiding citizens. The boys ages rum from sixteen to thirty years, the wirls' from sixteen to forty; in the girls' colony for preparatory training, from twelve to sixteen years.

These boys and girls at first live in the colony houses, going out to work by the day. Later, if proven trustworthy, they arr allowed to live at the houses where they work, using the colony houses as social centers for their leisure hours. Both boyn and rirls living in the eolonies are encouraged to come back to the parent institution for dances, band concerts. nnovins-picture mutertainmonts, and any nooded medical attention.

Chmele and sunday-sehool privileges are allowed to all who care to take advantage of them. For the rirls, classes are provided in the domestic arts. mending. letter writing, ete. 
Pianos and Victrolas are in use in all the houses, and girls who show ability are given musical instruction.

The colony houses and their activities are regularly inspected by a parole agent, who also visits the houses in which the colony boys and girls are employed.

Earnings are spent for housing, clothing, and savings-bank accounts, and-to the extent of fifty cents a week-for pleasures and personal expenditures. About one-third of the earnings go into savings, thus encouraging each individual in habits of thrift.

The results of the colony system we have found to be more self-respect, more hope, more happiness for individuals, and for the institution an atmosphere of hope that stimulates energy and industry, lessening the number of discipline cases.

If there was any lack of proof that our system, as devised and carried out, is practicable and workable, it was to be found in the fact that during my absence of two months at the Plattsburg Officers' Training Camp, in the summer of 1918, two new colonies for girls-the one at East Aurora and the one at Syracuse-and one new farm colony for boys-the Lawrence Farm Colony-which had been opened just before I went away and had not been thoroughly organized, went on successfully to complete organization without my having to lend a hand or advise in any way.

\section{Conclusions}

1. We believe that with better facilities for manual, industrial, and vocational training in our public-school system, to make up for the lack of opportunities for physical development, home training, and apprenticeship such as existed in the past, many of the border-line cases will be saved in community life and will never need asylum or custodial care.

2. From now on, we should devote our energies toward enlargement along the lines of colonization, to rehabilitate as far as possible the patients that come to us and to return their services to the state, thus vacating many of the beds in our existing institutions and making them available for younger and more socially dangerous cases.

3. The services of many of these women could well be utilized in large centers of population for domestic work, hand 
laundry, and sewing, thus in no way materially competing with native or naturalized American labor. At least 20 per cent, and I believe 40 per cent, of all feebleminded and borderline cases can be very successfully and economically so handled.

4. There is ample opportunity for colonization of all the available trained men on various parcels of state-owned land and on abandoned or undeveloped farms, where such labor is especially needed. At the same time the individual is rendered happy, contented, and self-sustaining in an environment well suited to his mental state.

I am firmly of the belief that if this colony system is continued and proves as successful as it has in the past-which I am sure it will-we shall be able to provide in such colonies for at least one-half of all the feebleminded who will have to be cared for by the state of New York because of dependency or delinquency. This method of caring for them will save the state not only the hundreds of thousands of dollars that would otherwise be spent annually for the maintenance of these people, but also the overhead expense of $\$ 1,000$ per bed for from fifteen to twenty thousand cases. If we only consider the interest on this investment at 5 per cent, it will mean. a matter of a million dollars saved in interest on the twenty million that would be spent in building for these twenty thousand people.

And more, these cases will be made much happier and more contented by this method of treatment, much more normal in their lives and activities, while at the same time the public will have the benefit of labor which otherwise, according to present indications, will not be available.

In connection with such a colony system, many of the boys and girls who have proven to be entirely trustworthy and amenable to ordinary family life will be placed on paroleboys on farms and girls with good families-to the extent of some five thousand at least.

During the past ten years, I have seen many boys and girls thus rehabilitated, and the fact that a few fail on first trial or even repeatedly is no sure proof that we were mistaken in our judgment of their ability to live outside the institution. Often I have seen these failures succeed almost immediately 
when placed in another enviromment, and continue to suecerel from thence on; posibly the previons experience of failure was the best lesson they could have had. Most of us normai inctividuals hare at one time or another been at the point of failure, and probably would have failed hat indulgent parentand frients not griven us a chance to try again and ret again until we eventually found ourselves. Noll should a sinall mum ber of complete failmes lead to the condemmation of a system that is proving suecessful in the great majority of cases, witl benefit hoth to the individual and to socienty. 



\title{
SOME NEW PROBLEMS FOR PSYCHIATRIC RESEARCH IN DELINQUENGY*
}

\author{
THOM.1. W. SALMON. M.1).

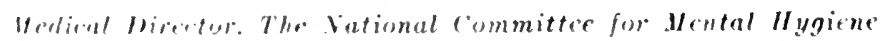

$T^{T}$ is no lonere necessary to dwell upon the value of eareful 1 psychiatric examinations of prisoners and persons aceused "if erime. Demonstrations made in this eomntry during the last few years go far toward indicating that those disorders of combuct which we eall crime and delinqueney ean be no more suceessfully managed without investigating the state of the organ of conduet than disorders of other kinds can be ireater without mulerstanding the processes responsible for them. First in the children's courts-from which lessons of wen wider application may yot come-and later in nearly wery kind of eriminal-court procedure, psychiatric studies have come to be regarded by many judges as a routine part of judieial investigation. One has said that he would not continue his work "if he wer" deprived of the benefit of his isychiatrie coadjutor.",

The extension of such work to eorrectional institutions was, in the borinning, solely for the purpose of detecting those individuals for whom we have more appropriate receptacles than prisons and reformatories, but, notably at Sinc Sing Prison and the United States Disciplinary Barracks at Jort lavenworth, systems of intra-institutional classification and management have arown up with the psychiatric study of prisoners as their corner stone.

Merely to sive a partial list of the well-organized psychiatrie clinies dealing with erime and delinqueney that were in operation elsewhere than in children's courts when we entered the war will indicate the rapid growth of this new method of -tudying erine. 'The elinies of Fort Leavenworth, Sing Sing, the Police Department and the Department of Corrections in

- Rand al the cleventh annual meting of the American Institute oi Criminal

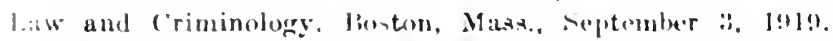

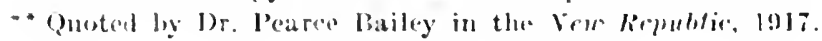



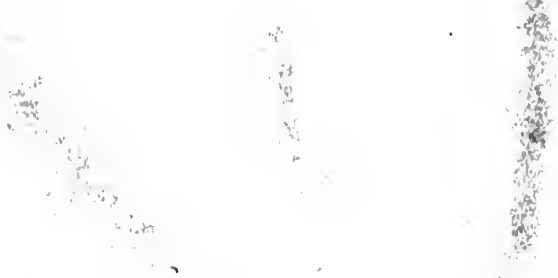

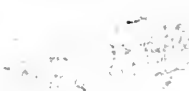
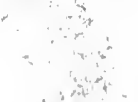

$\therefore$

atid

ind:

Hes.

Thers

4 in

1)

$x_{0}+1$

$x=5$

andist

$\therefore+y+x^{2}$

a

ad

is

$y^{2}=2,2$
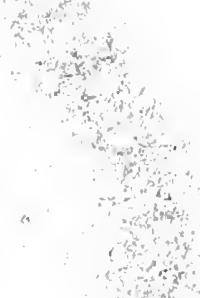

is

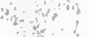

(1)

$2=-1$

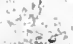

$40 x+4$

sice?
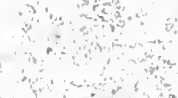

$7 x^{2}$

$\frac{y}{2}$ 


\section{UNIVERSITY OF CALIFORNIA LIBRARY BERKELEY}

Return to desk from which borrowed.

This book is DUE on the last date stamped below.

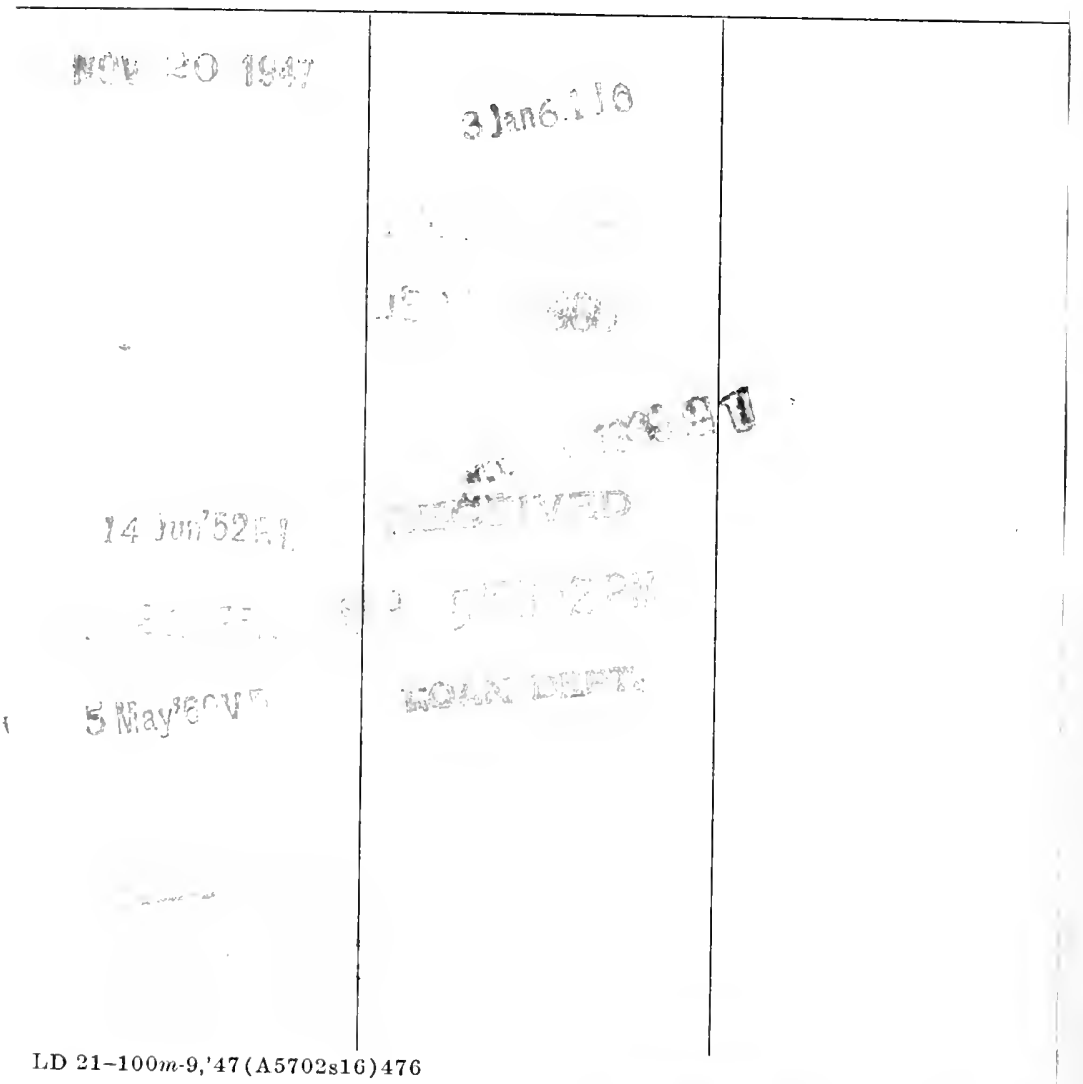


